\title{
Community Forest Management: A Strategy for Rehabilitation, Conservation and Livelihood Sustainability: The Case of Mount Oku, Cameroon
}

\author{
Jicenta N. Foncha*, Dora Mojoko Ewule \\ Department of Development Studies, Pan African Institute for Development-West Africa (PAID-WA) Buea, Buea, Cameroon \\ Email: jacinta_foncha@yahoo.com
}

How to cite this paper: Foncha, J. N., \& Ewule, D. M. (2020). Community Forest Management: A Strategy for Rehabilitation, Conservation and Livelihood Sustainability: The Case of Mount Oku, Cameroon. Journal of Geoscience and Environment Protection, 8, $1-14$. https://doi.org/10.4236/gep.2020.82001

Received: August 2, 2019

Accepted: January 19, 2020

Published: January 22, 2020

Copyright $\odot 2020$ by author(s) and Scientific Research Publishing Inc. This work is licensed under the Creative Commons Attribution International License (CC BY 4.0).

http://creativecommons.org/licenses/by/4.0/

\section{(c) (i) Open Access}

\begin{abstract}
Well-managed forests are major sources of livelihoods for the fringed communities. However, the remoteness, inaccessibility of most forested areas coupled with conflicts from adjacent forest communities, who often depend on it for livelihood is a daunting task in implementing conservation, viz-a-viz the Sustainable Development Goals. The Mt Oku forest is a unique, remote but represents novelty in forest management in remote areas in Cameroon, with devolution of management rights. The forest is well noted for its high level of endemism. This study is focused on the legal, institutional, socio-economic and regulatory framework put in place, for appropriate conservation and livelihood sustenance as forest management rights were devolved to the local community. A multidimensional framework guiding the development of testable hypothesis that assesses the relationship between the forest users' activities and forest degradation, which have a multiplier effect on the SDGs, was used. The alternate livelihood options/strategies and benefits after the institution of the Forest Management Project (FMP) was examined in randomly selected frontline and secondary villages. Selected Participatory Rural Appraisal (PRA) tools and registers from FMIs aided relevant data collection. The results indicated a significant relationship $\left(\chi^{2}=0.65 .4, \mathrm{p}=0.00\right)$ between the activities of forest users and forest degradation. Adopted alternate livelihood strategies/options include, direct employment, tourist guides, bee farming, agricultural intensification, agroforestry, capacity building for skill acquisition, selective exploitation and sales of Prunus spp. Forest regeneration strategies ranged from, forest guards, removal of exotic species, forest enrichment, raising nurseries, fire tracing, etc. It is concluded that giving greater access and ownership of
\end{abstract}


forest to the local community in the Mount Oku Region, led to transparency, accountability and social stability, which contributed tremendously both to the recovery and conservation of forest for improved livelihoods. However there is a dire need for the reinforcement of mechanisms for capacity building to improved livelihoods and conservation and the implementation of a system where stakeholders enjoy favorable conditions for information exchange and learning.

\section{Keywords}

Forest Management Institution, Livelihoods, Conservation, Forest Management Plan, Sustainable Development Goals

\section{Introduction}

Well-managed forests are major sources of livelihoods for the fringed communities and genuinely contribute to rural development and the economic dependence of the communities; thus, a tool for Sustainable Development (Alden \& Mbaya, 2001). However, according to the later, the rights and responsibilities of all stakeholders over the forest resource use and management must be clearly defined. Forests do not occur as "Island"; there are communities living either in or adjacent to the forests. They tend to be custodians and use indigenous knowledge, customary laws and practices in the use, management and protection of the forest (Sunderlin et al., 2007). Today, increasing population, changes in land use and quest for livelihood sustenance has led to encroachment in to forests ultimately leading to degradation, with the local communities suffering most. In most developing countries, the poor and vulnerable (women family heads, widows) often are excluded from land acquisition due to traditional land tenure practices, which is based on hereditary. These groups of people have no other option but are driven in to the forest in search of agricultural lands, Non-Timber Forest Products (NTFP) collection to meet up with livelihoods, thus putting pressure and threatening the health of forests (Pulhin \& Makato, 2008). The remoteness and inaccessibility of most forests makes it challenging for most governments to have significant presence and exercise full control, consequently failure of most conservation efforts. Apart of contradictory aspects in the legal system of Forest Management Plans (FMP) between government institutions and customary laws and practices of the communities governing the forests, where decision-making is dominated by the state, Asanga (2001) and Kvitashvili (2005) reported that the traditional Top-bottom conservation approach in forest management is often characterized by inadequate and inconsistent law enforcement and application. This creates overlap between authorities and unclear division of responsibilities, a major cause of conflict over resource use and management and hinders the process of Sustainable Forest Management (SFM).

New approaches (DANIDA, 2007; Pulhin \& Makato, 2008) of governance place 
strong emphasis on community participation in decision making by communities, civil society (NGOs), with the state assuming the responsibility as coordinator. With greater access and ownership rights given to the community (decentralization and devolution of management rights) this creates transparency, accountability, social justice (stability) and peace; major component for Sustainable Forest Management (SFM). These approaches ties with the concept of Community Participation in Development Planning and project management (Bamberger, 1988). The approach clearly advocates for the following: organization and group involvement; project implementation method, which the community are helped to understand their needs and identify possible solutions to their challenges; stages of project in which the stakeholders are involved; scope of the project and stakeholders with particular attention to poor and vulnerable, who have always been ignored in most community projects. As noted by (Paul, 1987), Community Participation is based on efficiency, effectiveness, cost and benefit sharing. (Alden, 2003) noted that, community participation in development and project management must address livelihood concern; where local people move from position of subordinate beneficiaries to regulate their resources of livelihood with a longer term perspective. This will help secure land tenure rights by identifying and placing under local jurisdiction and socio-spatial boundaries; democratization; grass root participation, good governance especially in conservation and management of biological diversity; this is applicable in Community Forest Management (CFM).

Community Forest Management is a form of Participatory Forest Management (PFM) based on the aspiration and needs of communities and the potentials of their forest and lands as a means to establish just, equitable and sustainable form of land and resource use rights and management (Mulugeta \& Melaku, 2008). This involves numerous stakeholders with diverse interest, playing different roles, consequently having different objectives, with the main objective being the arrest of forest degradation, secure access and ownership of forest resources and increase benefits through empowerment capacity building (Sharpe, 1988; Leeuwis, 2000; Lamelas, 2000). The decentralization and devolution of forest resource management for local development, transfer of ownership and competence to local communities as an appropriate rational for Sustainable Forest Management (SFM) was used to describe CFM as an arrangement in PFM (Headley, 2001; Brown et al., 2002; Larson et al., 2007; Wunder, 2007). Foncha, (2012) reported that CFM takes in to consideration activities (NTFP and fuel wood collection, hunting, farmland and farm tools among others) associated with local forest communities that accelerates forest degradation and conflicts; seeking ways to address them in a participatory manner for the conservation of biodiversity.

The Mt Oku forest is an important biodiversity hot spot in Cameroon with a high level of endemism. Within the last decades, the eco-site has rapidly degraded and is amongst the earliest to have benefited from forest decentralization and devolution policies in the country. This was facilitated by the 1994 Forestry 
law and the 1998 Manual of Application (MINEF, 1994, 1998). These policies permits the establishment of legally recognized community forests, in which management of a forest can be devolved to the communities bordering the forest; on the basis of an agreed Forest Management Plan (FMP). The creation of the Kilum/Ijim Forest Project (KIFP) had as stakeholders, the traditional councils including communities, the government and the conservator (Birdlife international). It proceeded with the creation of a Technical operational Unit (TOU), for the KIFP to manage the proposed Core conservation area that was gazetted (Plant Life Sanctuary), this was followed by the creation of Forest Management Institutions (FMI). Using Participatory Rural Appraisal tools, information (on forest resources, history of use, availability of forest resources and traditional rules governing resource use) facilitated the drawing up and implementation of Simple Management Plan (SMP); a Forest Management Plan was further drawn up which comprised the blending of Indigenous Knowledge and scientific methods.

This study is focused on the legal, institutional, socio-economic and regulatory framework put in place, for appropriate conservation and livelihood sustenance as forest management rights was devolved to the local community. The work: a) Identifies and rank community activities that led to forest degradation; b) Examines the alternate livelihood options after the institution of the Forest management project (FMP); c) assesses the status of forests before and after the institution of (FMP); d) examines the services rendered by FMIs in the rehabilitation of the forest.

\section{Materials and Methods}

\subsection{Description of the Study Area}

Mount Oku forest in the Northwest Region of Cameroon is located between longitude $10^{\circ} 20^{\prime} \mathrm{E}$ and $10^{\circ} 35^{\prime} \mathrm{E}$ and latitude $6^{\circ} 07^{\prime} \mathrm{N}$ and $6^{\circ} 17^{\prime} \mathrm{N}$ (Figure 1). The forest area is made up of the Kilum Mountain range and the Ijim Ridge forests. Located $3011 \mathrm{~m}$ above sea level, it covers 20,000 ha (Asanga, 2002). The mountain is part of the Western Highlands of Cameroon, commonly referred to as the Bamenda Highland. The summit of the mountain is very cold and clouded, with mean maximum temperature ranging between $16.5^{\circ} \mathrm{C}-19^{\circ} \mathrm{C}$ and mean minimum temperature between $19^{\circ} \mathrm{C}-10.5^{\circ} \mathrm{C}$, while the rainfall varies from 2850 to $3050 \mathrm{~mm}$ yearly.

The area experiences two seasons (rainy and dry). The rainy season runs from May to September and the dry season between October and April (Neba, 1982; Numbem, 1985). From the prevalence of mist and cloud, the humidity is high (about 90 percent) and the incidence of sunshine low (Macleod, 1986).

Geologically, Mount Oku is formed on volcanic rocks (Tertiary basalt and Trachyte lava), though some uplifting of older granite and gneiss basement rocks has also occurred (Neba, 1982; Furon, 1963). The soils therefore vary greatly. They are strongly influenced by the parent materials, altitude, topography and human activities. 


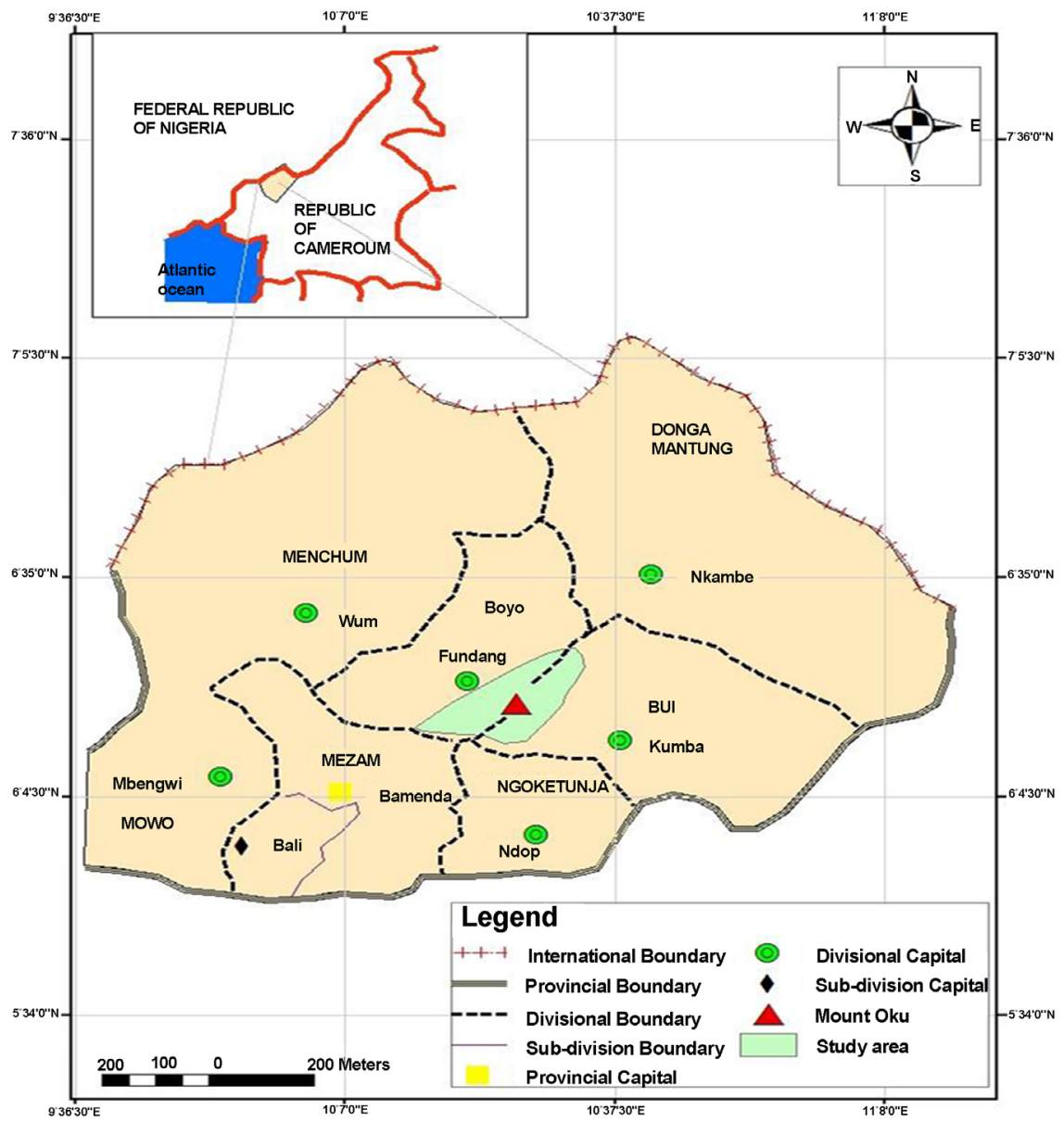

Figure 1. Map of the northwest region of cameroon showing the Mount Oku forest. Source: Asanga, 2001.

Mount Oku, like other mountain ecosystems possesses unique flora with numerous endemic species. This mountain supports the best surviving examples of plant species, which formerly covered the mountains of the Western and Bamenda Highlands. The whole of the Mount Oku Region was originally covered with forest, which extended from about $2100 \mathrm{~m}$ up to the summit plateau at $2900 \mathrm{~m}$. Grazing, burning and agricultural encroachment led to an extensive degradation of the vegetation, making it a mosaic of various communities such as moist montane, degraded montane, bamboo scrubland and trees, grassland (Diamond \& Hammilton, 1980; Stuart, 1986).

There are two main groups of rural people in the Oku region: the settled farmers and herdsmen. These farmers are semi Bantu in origin and are of three tribal groups: Nso, Oku and Kom. They practice mixed agriculture of annual and perennial crops and have a few animals. Most of the herdsmen are Fulanis (Mbororos) of Jaffren tribe, who came to Western Cameroon Highlands at the end of the German occupation in 1915. They graze the uncultivated grasslands by the right of arrangement settled with inhabitants (Nkwi \& Warner, 1982). The first settlers in the Oku Region brought with them the political organization which originated in the Borno State of Nigeria in which a chief or Fon had great 
prestige and authority. The Fon was aided by a traditional council of seven lords or Fais, who helped in the government of the realm. This system still exists and it is respected, although it has declined in importance in recent years (Numbem \& Thomas, 1985). In fact, the people around the Kilum-Ijim forest, like elsewhere in the North West Region of Cameroon, still operate on the basis of a traditional central political system (Thomas et al., 2001). The Fon and Kwifon have traditional custody of the land and natural resources and defacto ownership.

The population uses the forest for a broad array of products, especially honey, fuel wood, medicine, bush meat, timber for building materials and for carving, and NTFPs. Most watercourses in the study area originate from the forest, which is widely recognized as having an important role as a water source. To the local population, the forest also has an important spiritual and cultural value (Asanga, 2001, 2002; Gardner, et. al. 2001).

\subsection{Sampling Techniques}

The study started with a reconnaissance survey from April 2010-December 2010, to get background information of the study area. During this survey three Fondoms (Nso, Oku, and Kom) were identified that make up the Mount Oku Forest Region. This was followed with transect walk, with the aid of two field assistance that were familiar with the study area; the different stakeholders were identified (Forest Management Institutions (FMI), Forest Users Groups (FUG), Traditional Authorities (TA) and Extension Workers). Using purposive sampling, FMIs were chosen based on frontline and secondary villages. For each of the Fondoms, one frontline and one secondary FMI were chosen except for the Nso Fondom that has one FMI and it's a frontline FMI, these gave a total of 521 respondents. The Participatory Rural Appraisal tool (PRA) was used in collecting primary data; the instruments used included: questionnaires, Semi-structured Interview (SSI), group discussions and transect walk. Attendance registers of the various FMIs were also investigated.

\subsection{Data Analyses}

Apart from the institutional analyses and development framework, data was also subjected to descriptive and inferential statistics (chi-square, and correlations) to test hypotheses using SPSS package version 17.5.

\section{Results and Discussions}

\subsection{Identification and Ranking of Activities That Led to Degradation}

Within the Mount Oku Forest region, the indigenous population carried out a variety of activities for livelihoods that facilitated the degradation of the forest (Table 1). Some of the forest activities were identified as the main causes of forest degradation and the severity of their impacts stood in the order of: logging $>$ agriculture $>$ fuel wood collection $>$ grazing $>$ NTFPs collection $>$ bush fire $>$ hunting. 
Table 1. Identification and ranking of factors of forest degradation on Mount Oku, North West Region of Cameroon.

\begin{tabular}{cccccccccc}
\hline & Factors & Anyajua & Bikov & Emfveh-Mii & Mutef & Upper Shingai & Total & Percent & Ranking \\
\hline 1 & Fuel wood extraction & 19 & 10 & 29 & 15 & 15 & 88 & 16.89 & 3 rd \\
2 & Agriculture & 18 & 23 & 31 & 12 & 26 & 110 & 21.11 & 2 nd \\
3 & Grazing & 7 & 19 & 30 & 12 & 17 & 85 & 16.31 & 4 th \\
4 & Logging & 22 & 19 & 40 & 25 & 21 & 127 & 24.38 & 1 st \\
5 & Collection of NTFB & 4 & 12 & 14 & 19 & 8 & 57 & 10.94 & 5 th \\
6 & Hunting & 3 & 3 & 10 & 4 & 5 & 25 & 4.80 & 7 th \\
7 & Bush fire & 3 & 5 & 11 & 2 & 8 & 29 & 5.57 & 6 th \\
& TOTAL & 76 & 91 & 165 & 89 & 100 & 521 & 100 &
\end{tabular}

Source: Researchers field work (2011).

At the level of individual communities, except in Bihkov and Upper Shinga where agriculture was ranked first, logging, fuel wood collection and grazing were also ranked as predominant activities in all the communities. The spearman correlation between these forest activities and forest degradation revealed a highly significant positive strong relationship $(\mathrm{r}=0.474, \mathrm{p}<0.01)$ (Table 2). This indicates that as the activities intensify, forest degradation is aggravated.

In the area, the logged wood was used for carving, building and construction, production of traditional musical instruments, and fencing to provide fodder for grazing. The moment product correlation indicated that logging and logging for fuel wood use was positively but insignificantly correlated $(r=0.209, \mathrm{p}>0.05)$. Based on traditional principles in the area (indigenous knowledge) fresh wood must not be taken from the forest for fuel wood. The traditional institutions implements "watch dogs" to supersede defaulters. Logging destroys the canopy, which protects the forest and causes fragmentation and destruction of habitat and water shed (State of the Forest, 2006). In the area, in order to meet food demands of the increasing population worsen by insecure land tenure systems, forest agriculture was ranked the top second of the forest degradation factors. The activity was characterized by bush fire that voids the soil with vegetation. This resulted to fragmentation and habitat destruction. Due to easy accessibility and simplicity of use and irregular income, local people depended on fuel wood (ranked third) as a source of domestic energy and income. Within the Mount Oku forest area, the number of cattle in the area surpasses the carrying capacity. Cattle rearing also promoted vegetation lost. Animals of the area browse repeatedly on succulents' plants preventing regeneration. Trampling of the animals' disintegrated the soil, facilitating erosion, which prevented growth of vegetation. Eighty percent of the population seriously agreed that Footpaths created by grazers facilitated erosion that enhanced the rate of fragmentation of the forest. Besides burning by crop farmers, grazer in the area often set fires in the forest. The practice of burning by grazer was to create new flush of pasture was seen as destructive to the states of the forest. Non-timber products extraction was associated 
Table 2. Chi-square statistical analysis of the relationship between human activities and land degradation.

\begin{tabular}{|c|c|c|c|c|c|c|c|c|c|c|}
\hline Human activities & $\begin{array}{l}\text { Very Highly } \\
\text { Degraded }\end{array}$ & $\begin{array}{c}\text { Highly } \\
\text { Degraded }\end{array}$ & $\begin{array}{l}\text { Moderately } \\
\text { Degraded }\end{array}$ & $\begin{array}{c}\text { Slightly } \\
\text { Degraded }\end{array}$ & Intact & Total & $x^{2}$-cal & $x^{2}$-crit & d.f. & $\mathrm{p}$-value \\
\hline Fuel Wood Extraction & 31 & 35 & 6 & 10 & 6 & 88 & & & & \\
\hline Agriculture & 40 & 28 & 24 & 10 & 8 & 110 & & & & \\
\hline Grazing & 29 & 16 & 19 & 12 & 9 & 85 & 65.4 & 36.4 & 24 & 0.000 \\
\hline Logging & 70 & 24 & 20 & 5 & 8 & 127 & & & & \\
\hline NTFP collection & 15 & 11 & 11 & 12 & 8 & 57 & & & & \\
\hline Hunting & 5 & 5 & 5 & 5 & 5 & 25 & & & & \\
\hline Bush Fire & 6 & 6 & 5 & 5 & 7 & 29 & & & & \\
\hline Total & 196 & 125 & 90 & 59 & 51 & 521 & & & & \\
\hline
\end{tabular}

with medicinal plants, which were not harvested sustainably. A majority (89.5\%) of the population depended heavily traditional medicines due to inadequate medical services and their low socioeconomic status. Theses forced the population to depend solely on the forest consequently exacerbating degradation.

The result in Table 2 revealed that the calculated $\chi^{2}$ value of 65.4 was found to be greater than 5 the critical $\chi^{2}$ value of 36.4 needed for significant at 0.05 level of significance with 24 degrees of freedom. With this result, the null hypothesis that states that there is no significant relationship between human activities and degradation of the forest is rejected. It therefore means that there exist a significant relationship between human activities and forest degradation.

\subsection{Alternate Livelihoods}

The institution of the Forest Management Project (FMP) was accompanied by a number of alterative livelihood activities: direct employment either in the formal or informal sector, capacity building, cultivation of seedlings for sale, sustainable harvesting and sale of Prunus, bee farming and credit and loan facilities (Table 3). The engagement of forest users in these alternate livelihood activities reduced drastically pressure on the forest.

Direct and permanent employment either with the government or informal sector registered zero in all the FMIs, this is because most forest users did not have formal education and lacked skills. Capacity building registered $20.90 \%$, the project implemented livelihood diversification options through short-term vocational and entrepreneurial programs in order to divert communities interest from the forest. The program includes: tourist guides, driving, carpentry, hair dressing for men and women, trading, masons among others. Nurseries for seedling registered $16.80 \%$, during the early phases of project negotiation and using Participatory Rural Appraisal (PRA), the communities listed some forest resources that was important to their livelihood sustenance. These resources were sustainably removed and planted in their farms and nurseries, so as to keep the people out 
Table 3. Alternate livelihoods.

\begin{tabular}{|c|c|c|c|c|c|c|c|c|c|c|c|}
\hline & \multirow[b]{2}{*}{ Items } & \multicolumn{2}{|c|}{ Anyajua } & \multicolumn{2}{|c|}{ Bikho } & \multicolumn{2}{|c|}{ Emfveh-Mii } & \multicolumn{2}{|c|}{ Mutef } & \multicolumn{2}{|c|}{ Upper Shinga } \\
\hline & & $\begin{array}{l}\text { No. of } \\
\text { persons }\end{array}$ & Percent & $\begin{array}{l}\text { No. of } \\
\text { persons }\end{array}$ & Percent & $\begin{array}{l}\text { No. of } \\
\text { persons }\end{array}$ & Percent & $\begin{array}{l}\text { No. of } \\
\text { persons }\end{array}$ & Percent & $\begin{array}{l}\text { No. of } \\
\text { persons }\end{array}$ & Percent \\
\hline 1 & $\begin{array}{c}\text { Direct/Permanent } \\
\text { Employment }\end{array}$ & 0 & 0 & 0 & 0 & 0 & 0 & 0 & 0 & 0 & 0 \\
\hline 2 & $\begin{array}{l}\text { Capacity building/ } \\
\text { Skill acquisition }\end{array}$ & 16 & 13.45 & 20 & 10.7 & 14 & 11.11 & 12 & 17.39 & 107 & 20.9 \\
\hline \multirow[t]{2}{*}{3} & Improved seedlings & 31 & 26.5 & 40 & 21.4 & 36 & 28.57 & 7 & 10.14 & 86 & 16.8 \\
\hline & Harvest of Prunus & 28 & 23.53 & 24 & 12.8 & 32 & 25.4 & 16 & 23.19 & 109 & 21.3 \\
\hline 5 & Bee farming & 44 & 36.97 & 58 & 31 & 44 & 34.92 & 34 & 49.28 & 210 & 41 \\
\hline \multirow[t]{2}{*}{6} & Loans/credit facilities & 0 & 0 & 45 & 24.1 & 0 & 0 & 0 & 0 & 0 & 0 \\
\hline & Total & 119 & 100 & 187 & 100 & 126 & 100 & 69 & 100 & 512 & 0 \\
\hline
\end{tabular}

of the forest. Thus some members of the community/FMI were engaged in the nursing and selling of seedlings as their new occupation. Sustainable harvesting of Prunus Africana had 21.29\%; this was done collectively by FMIs in their areas of operation. It was a major source of revenue for the FMIs and was used to pay guards hired to watch the forest. Bee farming registered the highest with $41.02 \%$. Bee farming did not contribute to forest destruction. The community abandoned the traditional bee farming method, which used fire and destroyed the forest and engaged in the modern bee farming methods. The capacity building program included bee farming. There was also the creation of Honey cooperatives, this attracted most people in bee farming. A credit and Loan facility had insignificant contributions as this needed knowledge in bookkeeping that was lacking in the community. The absence of such skills made the FMIs to group themselves and form "Village savings and loan scheme". Among the FMIs studied, Bikov FMI had a credit and loan facility because of book keeping officer. This livelihood diversification options help to reduce pressure in the forest but not completely such as in the frontline villages of Mutef and Ayajua where forest encroachment were noticeable. These villages had the lowest level of livelihood diversification. The secondary villages were either commercial or administrative, thus was easy for them to engage in more livelihood activities.

\subsection{Reasons for the Implementation of a Community Forest Management}

In order to assess the level of forest degradation before and after the institution of FMP, this study established the reasons for the creation of FMP.

From Figure 2, the most dominant factor that influenced the implementation of a community forest management was serious degradation of the forest, which was associated with shortage of forest products (farm tools, fuel wood, mushrooms, and ropes amongst others). Population had to go a long distance to harvest these resources. The forest serves as an important site or religious rites of 


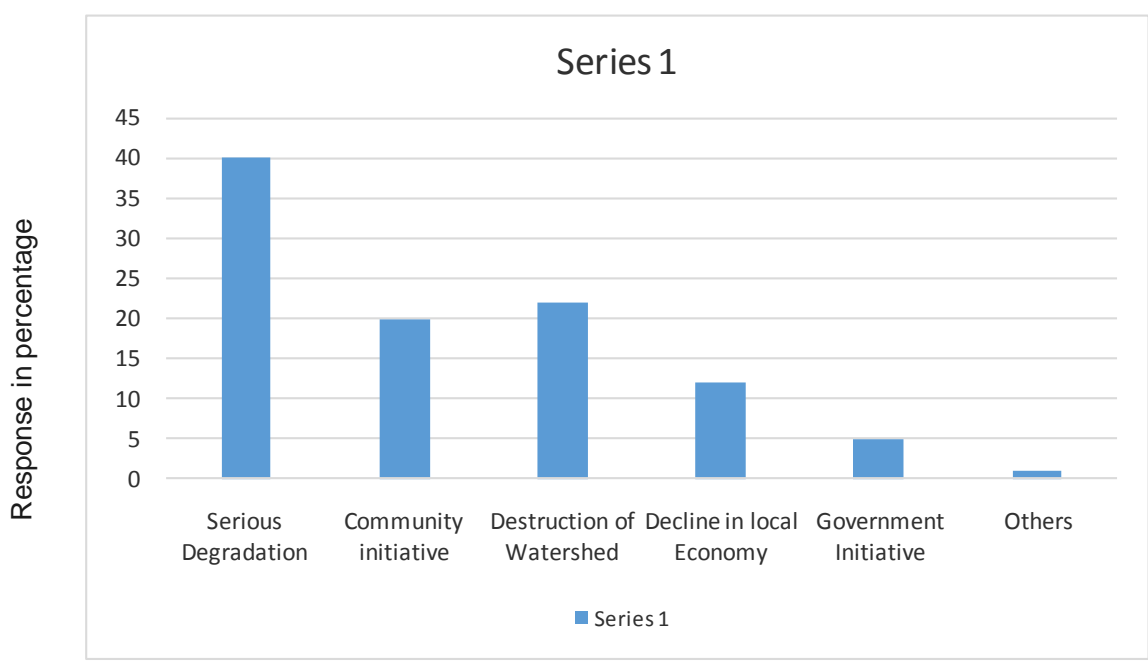

Reasons for setting up forest management project.

Figure 2. Reasons for the implementation of community forest management.

the Oku people as it host many ancestral shrines. To the people, the degradation of the forest seriously fragment the culture they uphold. This motivated many traditional groups in the village to highly support the idea of community project management.ss The long term use of indigenous knowledge in forest management; where for example women had no access to the forest; family heads (elderly men) went into the forest naked, and it is a taboo for either the youths or women to see the nakedness of elderly people and many sacred grooves. Keeping them out of the forest reduced pressure on the forest (Pers Com, Pa Nformi, 2011). Community Initiatives for forest management has also been reported by (Alden, 2003; Gardner et al., 2001), Cameroon has a high potential of generating income through timber and other forest resource, but the population around the Kilum/Ijim forest show a high level of motivation for forest management. The community's value their forest to the extent that they have willingly contributed significant time and efforts needed to manage the forest. They have voluntarily giving up the option of converting forests to other land use. Within the Oku forest area, there has been a significant loss of benefits derived from the forest, like loss of vegetation leading to loss of soil (erosion), soil impoverishment and consequent reduction in agricultural output. The loss of vegetation cover and accelerated erosion seriously affects watersheds. The Oku forest is a major watershed in the North West Region of Cameroon. The destruction of this watershed is one of the major reasons advanced for the creation of the FMP. In fact, problems arising from water quality and quantity degradation have been recurrent of recent. Economy was also advanced as one of the reasons for the creation of FMP. The scarcity of Non-Timber Forest Products (NTFP) affects the market trend of the community, reducing economic viability especially to women. Fear of extinction of endangered and endemic species and the maintenance of ecological integrity of the forests led to the Government initiative to carry out conservation program. 


\subsection{Status of the Forest before and after the Implementation of a Community Forest Management Project}

After the institution of the Forest management project, as shown in Figure 3 community mobilization, organization and capacity building coupled with the granting of Legal forest rights achieved forest rehabilitation and conservation success. The success was based on the degree of commitment of FMIs, their institutional stabilities. The FMIs contributed to improvement of state of the forest through: Maintenance of forest boundaries with the use of forest guards; forest regeneration projects like, clearing of forest boundaries, fire tracing, forest enrichment, removal of exotic species and raising nurseries. Upon gaining legal rights of access to "their forest", communities decided the discontinuation of any activity, which they considered were damaging to the health of the forest. For instance, banning of fuel wood exploitation for commercial purposes except dry wood for domestic use only. Grazing in the forest was not banned but restricted to areas of grass, which had to be fenced to prevent animals going into the forest to browse on young regenerating plants. The introduction of modern bee farming practices, which did not involve fire as the traditional bee farming method, avoided the destruction of the forest by bush fires. Regulated harvesting of farm tools, sustainable harvesting of NTFPs raised and improve productivity. Banning of hunting of rare and endemic species of animals for fear of extinction ensured conservation efforts. These also led to the reduction of footpath indicating a reduction of human activities in the forest.

\section{Conclusion}

Community Forest Management is a strategy for local communities to achieve Sustainable Economic Development. Communities need to be empowered to start managing their forests, by having access to and use sustainably the assets

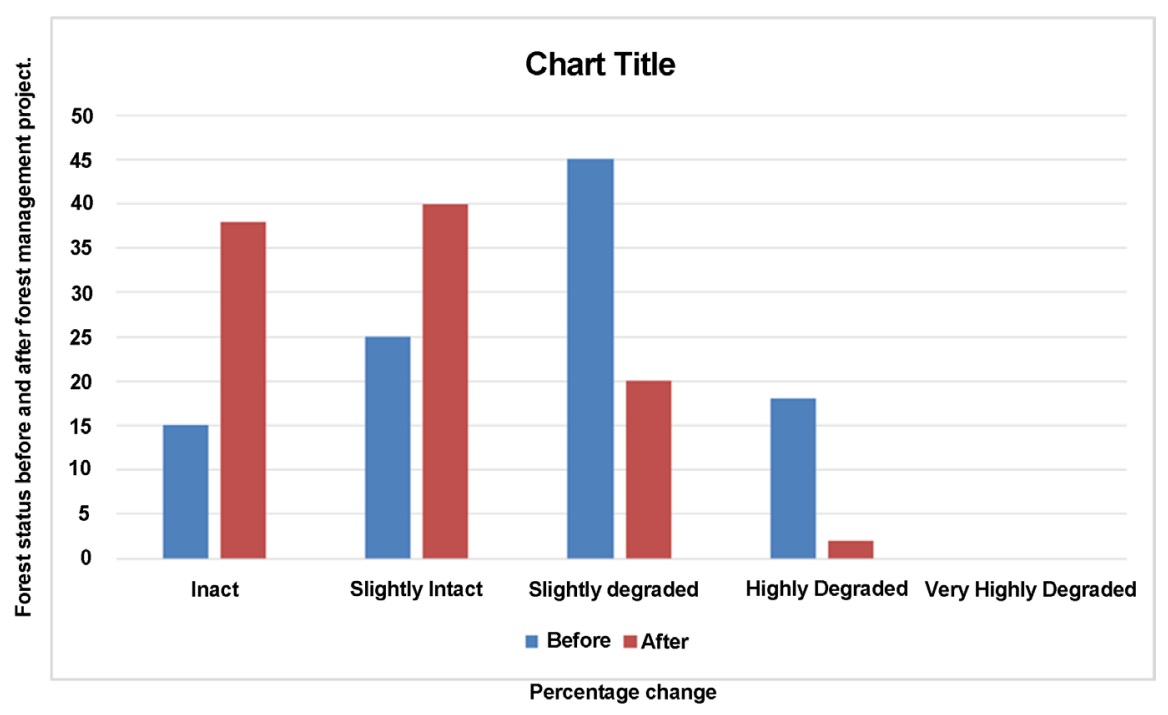

Figure 3. Status of forest before and after the implementation of community forest management. 
available to them. This study focused on the legal, institutional, socio-economic and regulatory framework put in place for sustainable forest management as management rights were devolved to local communities. In the area before the project, forest activities ranked as logging $>$ agriculture $>$ fuel wood collection $>$ grazing $>$ NTFPs collection $>$ bush fire $>$ hunting had rapidly degraded the forest. Except in Bihkov and Upper Shinga where agriculture was ranked first, logging, fuel wood collection and grazing were also ranked as predominant activities in all the communities.

There were significant differences in the states of the forest before and after implementation of a Forest Management Project with a student t-test value of 4.83 at the $95 \%$ confident interval. As a strategy for Sustainable Forest Management, Livelihood diversifications options included: direct employment with government or private sectors like tourist guides, forest guards. Sustainable prunes harvesting by FMIs registered 21.3\%; capacity building skills (community empowerment) which registered $20.9 \%$ included bee farming, carpentry, mansions, hairdressing, driving among others. The granting of legal forest rights led to rehabilitation and livelihood sustainability, through community mobilization, organizational and capacity building. It is concluded that communities need to be empowered to manage forest resources in their own interest; however, there is need to help communities understand that access to forest and management rights is contingent on a number of responsibilities.

\section{Acknowledgements}

The authors acknowledge contributions from Mr. Asanga Christain who assisted in data collection, Mr. Fai Nditone Wilfred former Project manager KIFP, and Dr. Anyingang Roland the statistician.

\section{Conflicts of Interest}

The authors declare no conflicts of interest regarding the publication of this paper.

\section{References}

Alden, L. W. (2003). Participatory Forest Management in Africa. An Overview of Progress and Issues. New York: Department for International Development.

Alden, W. L., \& Mbaya, S. (2001). Land Peoples and Forests in Eastern and Southern Africa at the Beginning of the 21st Century: The Impact of Land Relations on the Role of Communities in Forest Management (pp. 1-313). Nairobi, Kenya: IUCN Regional Office for Eastern Africa.

Asanga, C. (2001). Facilitating Viable Partnership in Community Forest Management in Cameroon: The Case of the Kilum-Ijim Mountain Forest Area. In E. Wollenberg, D. Edmunds, L. Buck, J. Fox, \& S. Brodt (Eds.), Social Learning in Community Forests. Rome: Center for International Forestry Research (CIFOR).

Asanga, C. (2002). Community Forest Management at the Kilum-Ijim Mountain Forest Region, Cameroon (p. 42). FAO Working Paper, Rome: Conservation and Sustainable Monument. 
Bamberger, M. (1988). The Role of Community Participation in Development Planning and Project Management. Washington DC: World Bank.

Brown, D., Schreckenberg, K., Sheperd, G., \& Wells, A. (2002). Forestry as an Entry Point for Governance Reform: Oversea Development Institute Forestry Briefing. London: Oversea Development Institute.

Danish Ministry of Foreign Affairs (DANIDA) (2007). Participatory Forest Management, Component Document (pp. 1-20). Tanzania: Environment, Peace and Stability Facility (MIFRESTA), Environment Support Program (ESP).

Diamond, A. W., \& Hamilton, A. C. (1980). The Distribution of Passerine Birds and Quaternary Climate Change in Tropical Africa (21 p.). London: Bird Life International.

Furon, R. (1963). Geology of Africa. Edinburg: Oliver and Boyd.

Gardner, A., De Marco, J., \& Asanga, C. (2001). A Conservation Partnership: Community Forestry at Kilum-Ijim. Rome: Rural Development Forestry Network.

Headley, M. (2001). National Forest Management and Conservation Plan, Jamaica. Kingston: Department of Forestry.

Lamelas, P. (2000). Integrating Stakeholders in Participatory Natural Resource Management: Ecotourism Project of El Limon Waterfall. Dominican: Caribbean Natural Resource Institute.

Larson, A. M., Pachelo, P., Toni, F., \& Vallejo, M. (2007). The Effect of Forestry Decentralization on Access to Livelihood Assets. Journal of Environment and Development, 16, 251-268. https://doi.org/10.1177/1070496507306220

Leeuwis, S. C. (2000). Reconceptualizing Participation for Sustainable Development: towards a Negotiation Approach. Development and Change, 31, 931-959.

https://doi.org/10.1111/1467-7660.00184

Ministry of Environment and Forestry (MINEF) (1994). Law No.94/01 of 20 January, to Lay Down Forestry, Wildlife and Fisheries Regulations. Yaoundé, Cameroon: Ministry of Environment and Forestry.

Ministry of Environment and Forestry (MINEF) (1998). Manual of Application of the Procedure for the Attribution and Norms of the Management of Community Forest, Cameroon. Yaoundé: Ministry of Environment and Forestry.

Mulugeta, L., \& Melaku, B. (2008). Participatory Forest Management; Best Practices, Lesson Learned and challenges Encountered (pp. 4-35). The Ethiopian and Tanzanian Experiences. FARM-Africa/SOS-Sahel.

Neba, A. S. (1982). Modern Geography of the United Republic of Cameroon. New York: Hamilton Printing Company.

Nkwi, P. N., \& Warner, J. P. (1982). Elements for a History of the Western Grass Fields.

Numbem, S. T. (1985). The Conservation of Oku Mountain Forest, Cameroon. Cambridge: International Council for Bird Preservation

Numbem, S. T., \& Thomas, D. W. (1985). The Conservation of Oku Mountain Forest, Cameroon. Cambridge: International Council for Birds Preservation.

Paul, S. (1987). Community Participation in Development Projects: The World Bank EXperience. Washington DC: Economic Development Institute.

Pulhin, J. M., \& Makoto, I. (2008). Dynamics of Devolution Process in the Management of the Philippine Forests. International Journal of Social Forestry, 1, 1-26.

Sharpe, B. (1998). First the Forest: Conservation, Community and Participation in South-West Cameroon. Africa, 68, 20-45. https://doi.org/10.2307/1161146

State of the Forest (SOF) (2006). The Forest of the Congo Basin. The Congo Basin Forest 
Partnership. Kinshasa: Community Based Forest Partnership.

Stuart, S. N. (1986). The Conservation of the Montane Forest of Western Cameroon. Yaoundé: International Council for Birds Preservation.

Sunderlin, W., Dewi, S., \& Puntodewo, A. (2007). Poverty and Forests: Multi-Country Analysis of Spatial Association and Proposed Policy Solutions (44 p.). CIFOR Occasional Paper, No. 47, Bogor, Indonesia: Center for International Forestry Research (CIFOR).

Thomas, O., Gardner, A., \& Demario, J. (2001). Devolution of Decision-Making: Lessons from Community Forest Management at Kilum-Ijim Forest Project, Cameroon. In R. Jeffery, \& B. Vira (Eds.), Conflict and Cooperation in Participating Natural Resource Management. Guatemala: Global Issues Series.

Wunder, S. (2007). Poverty Alleviation and Tropical Forest: What Scope for Synergies? World Development, 29, 43-46. 